\title{
Chronic hepatitis in childhood: the spectrum of the disease
}

\author{
F BORTOLOTTI, R CALZIA, A VEgNENTE, P CADROBBI, M RUGGE, \\ M ARMigliato, M G MARAZZI, R IORIO, C CRIVELlARO, R PISCOPO, \\ AND G REALDI
}

From the Clinica Medica 2 of the University and 3 a Cattedra Anat Patol of the University, Padua; Department of Infectious Diseases, Padua; 2nd Clinic of Infectious Diseases, Genoa; and Institute of Pediatrics, 2nd Faculty of Medicine, Naples, Italy

SUMMARY During a multicentre study of chronic hepatitis in childhood diagnosed by biopsy, the spectrum of the disease has been evaluated in 196 consecutive patients, including 157 from Northern Italy and 39 from Southern Italy. Only $31 \%$ of patients in the former group and $27 \%$ in the latter were symptomatic when first seen: the majority of cases being seen after familial screenings for hepatitis B virus (HBV) markers or during intercurrent infections, thus suggesting that the frequency of chronic hepatitis in childhood might be largely underestimated in our area. In Southern and Northern Italy $83 \%$ of symptomatic and $95 \%$ of asymptomatic patients were hepatitis B surface antigen (HBsAg) positive in serum; only $15(8 \cdot 3 \%)$ of these children were born to mothers known to be HBsAg positive at delivery, but a high circulation of $\mathrm{HBV}$ was found in their families: in fact more than $65 \%$ of household contacts in Northern Italy and more than $90 \%$ in Southern Italy had serological evidence of past or ongoing $\mathrm{HBV}$ infection. These data indicate that, although familial screenings for HBV could have enhanced the percentage of HBsAg positive asymptomatic cases, chronic hepatitis in Italian children is mainly caused by $\mathrm{HBV}$ infection acquired in the familial setting through horizontal transmission. Such findings also emphasise the importance of mass vaccination of infants as the most effective means to prevent chronic type $B$ hepatitis in childhood in our area. Among HBsAg positive children $55 \%$ had histological features of chronic active hepatitis and $85 \%$ were hepatitis Be antigen (HBeAg) positive in serum. Anti-HBe positive hepatitis was significantly more frequent in Southern than in Northern Italy in parallel with the significantly higher prevalence $(\mathbf{1 7 \%})$ of hepatitis delta virus infection in that area. Of the $16 \mathrm{HBsAg}$ negative cases included in the study three had autoimmune hepatitis, three Wilson's disease, one alpha antitrypsin deficiency, and nine had cryptogenic hepatitis, often associated to mild liver lesions resembling those seen in our adult patients with chronic non-A, non-B hepatitis unrelated to percutaneous exposure.

Multiple aetiological agents may induce chronic hepatitis in infants and children, including hepatitis $B$ and non-A, non-B virus infections and autoimmune or metabolic disorders, however the spectrum of the disease has never been evaluated in a large series of

Address for correspondence: Dr Flavia Bortolotti, Clinica Medica 2 , Policlinico, Via Giustiniani 2, 35100 Padova, Italy.

Received for publication 17 November 1987. paediatric patients. Data from the literature suggest that autoimmune and cryptogenic hepatitis are the most common types of chronic hepatitis seen by paediatricians in Northern Europe and in the United States, ${ }^{1-3}$ while little is known about areas such as Italy, where $\mathrm{HBV}$ infection is endemic.

In this multicentre study we have therefore evaluated the aetiology and related clinical features of chronic hepatitis diagnosed by biopsy in a large series of Italian children. 


\section{Methods}

PATIENTS

The aetiology and clinical profile of chronic hepatitis have been investigated in two groups of patients: (1) 157 consecutive children, aged $1-13$ years, seen at the Department of Infectious Diseases of Padua and at the 2nd Clinic of Infeetious Diseases of Genoa (Northern Italy) during a 10 year period (1976-85); (2) 39 consecutive children, aged 1-13 years, seen at the Institute of Paediatrics 2nd Faculty of Naples (Southern Italy) during a two year period (1984-85). The opportunity of including this series of patients, even if not comparable with the former group for number of cases and duration of observation, was suggested by the well known differences in the epidemiology of hepatitis $\mathrm{B}$ and delta virus infections between Northern and Southern Italy. ${ }^{45}$

None of the above institutions was a referral centre for highly selected liver diseases. The diagnosis of chronic hepatitis was based on one of the following clinical criteria: (a) symptoms of liver disease and/or hepatomegaly associated with increased transaminase concentrations for longer than six months; (b) increased transaminase concentrations and HBsAg antigenaemia for more than six months; (c) increased transaminase concentrations for greater than six months in the absence of extrahepatic causes of hypertransaminasaemia; and on liver histology. Liver biopsy was done by the Menghini technique after informed consent of parents.

Children with underlying systemic disorders such as leukaemia, thalassaemia and chronic uraemia, were excluded from the study. The aetiology of chronic hepatitis was established as follows: (1) hepatitis B: presence of HBsAg in serum; (2) non-A, non-B hepatitis: previous history of acute non-A, non-B hepatitis, as defined by conventional exclusion criteria; (3) drug or alcohol induced hepatitis: clinical history; (4) Wilson's disease: clinical features, haematological and biochemical parameters; (5)

Table 1 Aetiological subgroups of chronic hepatitis

\begin{tabular}{|c|c|c|c|c|}
\hline \multirow[b]{2}{*}{ Subgroup } & \multicolumn{2}{|c|}{$\begin{array}{l}\text { Northern Italy } \\
\text { (157 cases) }\end{array}$} & \multicolumn{2}{|c|}{$\begin{array}{l}\text { Southern Italy } \\
\text { (39 cases) }\end{array}$} \\
\hline & $n$ & $\%$ & $n$ & $\%$ \\
\hline HBsAg+ & 144 & $92 \cdot 0$ & 36 & $92 \cdot 2$ \\
\hline ( $\mathrm{BBeAg}+$ & 128 & $88 \cdot 8$ & 24 & $66 \cdot 6$ \\
\hline Anti-HBe & $16^{*}$ & $11 \cdot 1$ & $12 \dagger$ & $33 \cdot 3$ \\
\hline Anti-delta + & $5^{*}$ & $3 \cdot 0$ & $6 \dagger$ & $16 \cdot 6$ \\
\hline Autoimmune & 2 & $1 \cdot 2$ & 1 & $2 \cdot 6$ \\
\hline Wilson's disease & 2 & $1 \cdot 2$ & 1 & $2 \cdot 6$ \\
\hline Alpha $_{1}$ antitrypsin DEF & 1 & 0.6 & 0 & \\
\hline Cryptogenic & 8 & $5 \cdot 0$ & 1 & $2 \cdot 6$ \\
\hline
\end{tabular}

${ }^{*} \mathrm{p}<0.01$ versus $\dagger$. alpha $_{1}$ antitrypsin deficiency: documented abnormal phenotype; (6) autoimmune hepatitis: clinical features, hypergammaglobulinaemia, presence and titre of non-organ specific autoantibodies; (7) cryptogenic hepatitis: none of the above aetiologies.

HBV markers in serum, such as HBsAg, anti-HBs, $\mathrm{HBeAg}$, anti-HBe and antibody to hepatitis B core antige (anti-HBc), and antibody to hepatitis delta virus (HDV) antigen (antidelta) were investigated by commercial radioimmunoassay kits (Abbott Laboratories, Chicago). HBV-DNA in serum was determined by the method of Scotto et al. ${ }^{6}$

Non-organ specific autoantibodies were determined by immunofluorescence using rat liver, kidney and stomach substrates. A reaction at the serum dilution of 1:80 was regarded as positive for smooth muscle antibodies, while a titre of $1: 10$ was required for antinuclear antibody, antimitochondrial antibody and liver/kidney microsomal antibodies. Serum alpha $_{1}$ antitrypsin phenotyping was done by polyacrylamide gel electrophoresis with isoelectric focusing. Liver biopsies were undertaken between six months and two years after first observation and interpreted according to conventional criteria ${ }^{7}$ by the same pathologist who was unaware of the clinical diagnosis.

Statistical analysis of data has been performed by the Cochran-Cox test, the $\chi^{2}$ test, and the Fisher's exact test (computed by logarithmic approximation).

\section{Results}

The aetiology of the disease in the two groups of children is shown in Table 1. A significantly higher prevalence of HDV infection was found in HBsAg positive children in Southern Italy.

\section{HBs Ag positive hepatitis}

The main epidemiological and clinical features of hepatitis B in the two groups of children are shown in Table 2. Boys were prevalent in both groups, but particularly in Southern Italy. No correlation was found between age of the patients and features of liver disease. The clinical history at presentation was similar to the two groups: a small number of children were born to mothers known to be HBsAg positive (antidelta negative) at delivery, while $39 \%$ of patients in group 1 and $50 \%$ in group 2 had a household contact who was known to be HBsAg positive. This contact was sometimes a sibling already included in this series, so that 41 siblings (14 couples, three groups of three children and one group of four siblings) were recorded in group 1 and six couples of siblings in group 2. Almost half of the patients had no evidence of possible exposure to HBV in their clinical history, but when familial 
Table 2 Epidemiological and clinical features of $\mathrm{HBs} A \mathrm{~g}$ positive hepatitis at presentation

\begin{tabular}{|c|c|c|c|}
\hline & $\begin{array}{l}\text { Northern } \\
\text { Italy }(144 \\
\text { cases })\end{array}$ & $p$ & $\begin{array}{l}\text { Southern } \\
\text { Italy ( } 36 \\
\text { cases) }\end{array}$ \\
\hline Male/female & 1.4 & NS & $1 \cdot 7$ \\
\hline Mean age (years) & $6 \cdot 1 \pm 3 \cdot 5$ & NS & $4 \cdot 8 \pm 3 \cdot 1$ \\
\hline \multicolumn{4}{|l|}{ Clinical history } \\
\hline HBsAg positive mother at delivery & $13(9 \%)$ & NS & $2(6 \%)$ \\
\hline $\begin{array}{l}\text { Known HBsAg carrier among } \\
\text { contacts }\end{array}$ & $57(39 \%)$ & NS & $18(50 \%)$ \\
\hline Blood transfusions & $7(5 \%)$ & NS & 0 \\
\hline No apparent exposure to HBV & $67(46 \%)$ & NS & $16(44 \%)$ \\
\hline \multicolumn{4}{|l|}{ Type of presentation } \\
\hline Acute hepatitis & $19(13 \%)$ & NS & $9(25 \%)$ \\
\hline Non-specific symptoms & $22(15 \%)$ & $<0.05$ & 0 \\
\hline Asymptomatic & $103(71 \%)$ & NS & $27(75 \%)$ \\
\hline Hepatomegaly & $121(84 \%)$ & NS & $29(80 \%)$ \\
\hline Splenomegaly & $42(29 \%)$ & NS & $11(30 \%)$ \\
\hline
\end{tabular}

screenings for HBV markers were performed, a high circulation of HBV was found even in the families of such children, as shown in Table 3 . We could in fact examine the distribution of HBV markers in serum in 100 of 125 families in Northern Italy (average members: 3.4 ) and in 24 of 30 families in Naples (average members: 5.0). All household contacts of the patients (index cases) were included. The prevalence of HBV markers in these subjects was raised independently of the clinical history of the index case. In Naples, however, the number of HBsAg positive cases (mainly 'healthy' carriers) was significantly higher than in Northern Italy. Eight of nine families of antidelta positive patients were also investigated and clustering of HDV infection (two or three antidelta positive members) was found in seven of them.

Less than a third of patients came to attention because of symptoms suggestive of liver discomfort: $16 \%$ had acute non-resolved hepatitis B and $12 \%$ complained of transient symptoms such as nausea, vomiting and anorexia. Non-specific symptoms were recorded with a significantly higher frequence in Northern Italy than in Naples, probably because of different lifestyle and educational standards of families. The remaining children were asymptomatic (Table 2), although at physical examination many of them were found to have mild to moderate hepatomegaly; they had been referred for the following reasons: (a) $74(41 \%)$ were found to be $\mathrm{HBsAg}$ positive during familial screenings for HBV. Subsequent investigations showed increased transaminase concentrations with or without hepatomegaly; (b) 56 $(31 \%)$ were found to have increased transaminase concentrations at routine check up before adenoidectomy or tonsillectomy, or after the detection of hepatomegaly during intercurrent infections. Subse-
Table 3 Prevalence of $H B V$ markers in serum in the household contacts of children with chronic type B hepatitis

\begin{tabular}{|c|c|c|c|}
\hline Group A & $\begin{array}{l}\text { Northern Italy } \\
30 \text { families } \\
\text { (106 contacts) }\end{array}$ & & $\begin{array}{l}\text { Southern } \\
\text { Italy } \\
9 \text { families } \\
\text { (45 contacts) }\end{array}$ \\
\hline$\left\{\begin{array}{l}\mathrm{HBsAg}+ \\
\text { Anti-HBs and/or anti-HBc+ } \\
\text { All markers negative }\end{array}\right.$ & $\begin{array}{l}42(40 \%) \\
34(32 \%) \\
30(28 \%)\end{array}$ & $\begin{array}{l}\mathrm{p}<0 \cdot 01 \\
\mathrm{p}=\mathrm{NS} \\
\mathrm{p}<0 \cdot 01\end{array}$ & $\begin{array}{c}30(66 \%) \\
12(27 \%) \\
3(7 \%)\end{array}$ \\
\hline Group B & $\begin{array}{l}70 \text { families } \\
\text { ( } 242 \text { contacts) }\end{array}$ & & $\begin{array}{l}15 \text { families } \\
\text { ( } 90 \text { contacts })\end{array}$ \\
\hline$\left\{\begin{array}{l}\mathrm{HBsAg+} \\
\text { Anti-HBs and/or anti-HBc+ } \\
\text { All markers negative }\end{array}\right.$ & $\begin{array}{l}90(37 \%) \\
70(29 \%) \\
82(34 \%)\end{array}$ & $\begin{array}{l}p<0.01 \\
p=N S \\
p<0.01\end{array}$ & $\begin{array}{l}50(55 \cdot 5 \%) \\
35(39 \%) \\
5(5 \cdot 5 \%)\end{array}$ \\
\hline
\end{tabular}

Group $A=$ families of children who came to observation after detection of $\mathrm{HBs} A \mathrm{~g}$ positivity in a family member.

Group $B=$ families of children without history of apparent exposure to HBV in the household setting.

quent investigations discovered $\mathrm{HBs} \mathrm{Ag}$ positivity in serum. The large majority of patients were $\mathrm{HBeAg}$ positive, independent of age and severity of liver disease. A significantly higher prevalence of anti$\mathrm{HBe}$ positivity was found in Southern Italy (Table 1) in parallel with the significantly higher prevalence of HDV infection in that area.

Because features of $\mathrm{HBeAg}$ positive, anti-HBe positive and HDV associated hepatitis did not significantly differ between Northern and Southern Italy, biochemical and histological parameters have been pooled in Table 4 . Independent of the virological status, more than half of the patients had histological features of chronic active hepatitis (CAH), with associated cirrhosis in nine cases, and high transaminase concentrations. Of the 11 antidelta positive children, two presented with acute hepatitis, one with non-specific symptoms and eight without symptoms of liver disease, although all had hepatomegaly. Four of these patients were $\mathrm{HBeAg}$ positive (one of them had CAH) and seven were anti$\mathrm{HBe}$ positive (six had $\mathrm{CAH}$, with associated cirrhosis in two). Of 21 anti-HBe positive children without evidence of HDV superinfection but with abnormal ALT levels three were born to $\mathrm{HBsAg}$ positive mothers and four had been transfused in the perinatal period. The prevalence of blood transfusions in the clinical history was significantly $(p<0.05)$ more frequent in anti-HBe positive (14\% of cases) than in $\mathrm{HBeAg}$ positive $(2 \%)$ children. HBV-DNA in serum, investigated in 13 of these children could be detected only in two cases.

\section{HBsAg NEGATIVE HEPATITIS}

The main features of chronic hepatitis in HBsAg negative patients are shown in Table 5. Three 
Table 4 Biochemical and histological features in relation to virological status in children with chronic type B hepatitis

\begin{tabular}{|c|c|c|}
\hline Virologicalstatus & Liver histology & Median $A L T^{*}$ \\
\hline $\begin{array}{l}\text { HBeAg + /anti-delta - } \\
\text { (148 cases) }\end{array}$ & $\left\{\begin{array}{l}\mathrm{CAH}=81 \\
\mathrm{CPH}=53 \\
\mathrm{CLH}-\mathrm{MHL}=14\end{array}\right.$ & $\begin{array}{r}158 \\
80 \\
85\end{array}$ \\
\hline $\begin{array}{l}\text { HBeAg }+/ a n t i-d e l t a+ \\
\quad(4 \text { cases })\end{array}$ & $\left\{\begin{array}{l}\mathrm{CAH}=1 \\
\mathrm{CPH}=1 \\
\mathrm{CLH}=2\end{array}\right.$ & - \\
\hline $\begin{array}{l}\text { Anti/HBe }+/ \text { anti-delta }- \\
\quad(21 \text { cases })\end{array}$ & $\left\{\begin{array}{l}\mathrm{CAH}=12 \\
\mathrm{CPH}=6 \\
\mathrm{CLH}-\mathrm{MHL}=3\end{array}\right.$ & $\begin{array}{r}139 \\
70 \\
-\end{array}$ \\
\hline $\begin{array}{l}\text { Anti-HBe }+ \text { /anti-delta }+ \\
\quad(7 \text { cases })\end{array}$ & $\left\{\begin{array}{l}\mathrm{CAH}=6 \\
\mathrm{CPH}=1\end{array}\right.$ & $\begin{array}{l}150 \\
-\end{array}$ \\
\hline
\end{tabular}

${ }^{*} \mathrm{NV}<50 \mathrm{IU} / \mathrm{l} . \mathrm{CAH}=$ chronic active hepatitis; $\mathrm{CPH}=$ chronic persistent hepatitis; $\mathrm{CLH}=$ chronic lobular hepatitis; $\mathrm{MHL}=$ minimal histological lesions.

patients had high titres of antinuclear antibody (with associated haemolitic anaemia in two) and three had Wilson's disease. Four of these children were symptomatic and had severe chronic hepatitis. One patient, who was occasionally found to have increased transaminases had $\mathrm{MZ}$ phenotype for alpha $_{1}$ antitrypsin deficiency.

Of the nine children with cryptogenic hepatitis only one had a history of blood transfusions, without a clear cut episode of acute non-A, non-B hepatitis. In the other cases no possible source of infection could be found and no features of hepatitis were recorded in their household contacts. At variance with hepatitis B most of these cases had inactive, often lobular, hepatitis.

\section{Discussion}

More than two thirds of children with chronic hepatitis seen in this study were asymptomatic and came to observation after occasional serological testing or after the detection of hepatomegaly during intercurrent infections. This figure, even when considering only children with $\mathrm{CAH}$, seems to be significantly higher than that reported in adult patients, ${ }^{89}$ and suggests that the frequency of chronic hepatitis in childhood might be largely underestimated in our area. In Southern and Northern Italy more than $80 \%$ of symptomatic and more than $90 \%$ of asymptomatic children were $\mathrm{HBsAg}$ positive in serum. Although familial screenings for HBV markers could have enhanced the percentage of $\mathrm{HBs} \mathrm{Ag}$ positive asymptomatic cases, it is conceivable that chronic hepatitis in Italian children is mainly caused by HBV infection. This pattern of the disease seems to be quite different from that seen in Northern Europe and in the United States, where
Table 5 Epidemiological and clinical features of liver disease in the $16 \mathrm{HBs}$ Ag negative cases

\begin{tabular}{|c|c|c|c|c|}
\hline & $\begin{array}{l}\text { Autoimmune } \\
\text { H. } \\
\text { (3 cases) }\end{array}$ & $\begin{array}{l}\text { Wilson's } \\
\text { dis. } \\
(3 \text { cases })\end{array}$ & $\begin{array}{l}\text { Alpha } \\
\text { antitryp. } \\
D . \\
\text { (l case) }\end{array}$ & $\begin{array}{l}\text { Cryptogenic } \\
\text { (9cases) }\end{array}$ \\
\hline Malc/female & $0 \cdot 5$ & 3 & 1 & 0.5 \\
\hline Age range (years) & $3-12$ & $4-10$ & 4 & $2-13$ \\
\hline \multicolumn{5}{|l|}{ Type of onset } \\
\hline Acute hepat. & 1 & () & 0 & 1 \\
\hline Symptomatic & 2 & 2 & () & 4 \\
\hline Asymptomatic & 0 & 1 & 1 & 4 \\
\hline \multicolumn{5}{|l|}{ Liver histology } \\
\hline $\mathrm{CAH}$ & 3 & 2 & () & 2 \\
\hline $\mathrm{CPH}$ & 0 & 1 & () & 2 \\
\hline CLH-MHL & 0 & () & 1 & 5 \\
\hline Associated disorders & 2 & 2 & 0 & () \\
\hline
\end{tabular}

autoimmune and cryptogenic hepatitis represent the majority of reported cases. ${ }^{3}$ " 10 Such discrepancy may be explained on the basis of environmental or genetic factors that determine a high endemicity of HBV infection" and conversely a low prevalence of autoimmune hepatitis and alpha ${ }_{1}$ antitrypsin deficiency in the Mediterranean area. ${ }^{12}$

The epidemiological pattern of chronic hepatitis in this paediatric series also differs from that observed in adult patients in our country. A multicentre study from Giusti et al, ${ }^{11}$ including 1154 adults with chronic active hepatitis unrelated to alcohol or drugs shows, in fact, that $47 \%$ of patients older than 15 years are HBsAg negative in serum. The significantly lower prevalence of $\mathrm{HBsAg}$ negative hepatitis in children might have different explanations. The duration of the disease at the time of first observation is likely to be longer in adults than in children, so that some formerly HBsAg positive patients could have eventually cleared HBsAg from serum. This hypothesis is supported by the finding of both HBV-DNA and other HBV markers in the liver of some adults with cryptogenic hepatitis, ${ }^{1314}$ but contrasts with the results of longterm prospective studies showing a low rate of HBsAg clearance in patients with chronic type B hepatitis. ${ }^{15} 16$ Moreover exposure to blood and blood contaminated materials, that represent the main source of non- $A$, non-B hepatitis, is probably lower in children without underlying diseases than in adult patients. As a matter of fact only $4 \%$ of children with cryptogenic or HBV related hepatitis in this study had a history of blood transfusions. Few children were born to mothers known to be $\mathrm{HBsAg}$ positive at delivery while the majority of $\mathrm{HBsAg}$ (and all antidelta) positive patients had probably acquired infection from-a family contact, often a sibling, through inapparent parenteral spread. In fact familial screenings for HBV and HDV markers in 
Southern and Northern Italy showed a high circulation of HBV even among the household contacts of children without history of apparent exposure to $\mathrm{HBV}$, and a clustering of HDV infection. In Naples, where the average number of family members and the endemicity of $\mathrm{HBV}$ infection are higher, the percentage of $\mathrm{HBsAg}$ positive contacts is also higher than in Northern Italy. These epidemiological findings emphasise the role of $\mathrm{HBV}$ vaccine in the prevention of chronic type $B$ hepatitis of children in our area, but also suggest that only mass vaccination of infants will be effective, particularly in Southern Italy.

As regards the clinical features of chronic type $B$ hepatitis, in symptomatic and asymptomatic patients, high transaminase concentrations are suggestive of active liver lesions even if, in single cases, liver histology is mandatory to establish the diagnosis (and to detect associated cirrhosis). Chronic active hepatitis is the most frequent histological pattern, although severe disease and associated cirrhosis are relatively uncommon. ${ }^{17}$ Most children were still in the early, $\mathrm{HBeAg}$ positive phase of their illness when first seen, while 27 were already anti-HBe positive, although with abnormal transaminases. Anti-HBe positive hepatitis seems to represent an heterogeneous entity that probably includes: (1) a minority of children who are still replicating HBV-DNA and therefore are candidates to antiviral therapy; (2) patients who have recently seroconverted from $\mathrm{HBeAg}$ to anti-HBe but have not yet reached biochemical and histological remission: ${ }^{18}$ (3) children who have been transfused and possibly coinfected by a non-A, non-B agent (a history of blood transfusions was significantly more common among anti-HBe positive than in $\mathrm{HBeAg}$ positive patients); (4) infants born to $\mathrm{HBsAg}$ positive mothers, that maintain features of ongoing liver disease in the absence of circulating HBV-DNA; (5) patients with HDV superinfection. The close association between HDV superinfection and anti-HBe positivity, which is in keeping with the well known inhibitory effect of HDV on HBV replication, ${ }^{19}$ is reflected by the significantly higher prevalence of anti-HBe positivity in Southern Italy, where the endemicity of HDV infection is higher. ${ }^{5}$ In this series HDV infection was associated to a severe liver histology in six of seven anti-HBe positive children but only in one of four $\mathrm{HBeAg}$ positive cases: it is conceivable that these latter patients had a recent HBV infection with a high degree of viral replication (that could not be inhibited by HDV) and a poor immune response to infected hepatocytes.

Studies on the natural history of chronic type B hepatitis in children indicate that the disease usually evolves towards an asymptomatic $\mathrm{HBsAg}$ carrier state, after termination of $\mathrm{HBV}$ replication. ${ }^{16}$ Only few patients, including those with HDV infection, will maintain long lasting features of liver disease. ${ }^{18}$ This clinical pattern seems to be quite different from that of autoimmune hepatitis, often presenting with symptoms and signs of severe liver disease and early cirrhosis. ${ }^{21}$ Indeed all three children with autoimmune hepatitis in this study had severe $\mathrm{CAH}$ at presentation with extrahepatic manifestations in two cases.

At variance with hepatitis $B$ and autoimmune hepatitis, most of our children with cryptogenic hepatitis had mild liver lesions similar to those seen in our adult patients with sporadic non-A, non-B hepatitis unrelated to known parenteral exposure. ${ }^{21}$ The longterm outcome of the disease in these children remains to be elucidated.

\section{References}

1 Dubois RS, Silverman A, Slovis TL. Chronic active hepatitis in children. Am J Dig Dis 1972; 17: 575-82.

2 Alagille D, Gautier M, Hadchouel M, Herouin C. Chronic hepatitis in children. Acta Pediatr Scand 1973; 62: $566-70$.

3 Lidman B, Biberfels G, Sterner G, Norberg R. Chronic active hepatitis in children. A clinical and immunological long-term survey. Acta Pediatr Scand 1977; 66: 73-9.

4 Giusti G, Galanti G, Gaeta GB, Ruggiero G, Piccinino F. HBsAg carriers among blood donors in Italy: a retrospective survey of data from 189 blood banks. Hepato-Gastroenterol 1981; 28: 96-8.

5 Smedile A, Lavarini C, Farci P, et al. Epidemiological pattern of infection with the hepatitis $\mathrm{B}$ virus-associated Delta agent in Italy. Am J Epidemiol 1983; 117: 223-9.

6 Scotto J, Hadchouel M, Hery C, Yvart J, Tiollais P, Brechot $C$. Detection of hepatitis B virus DNA in serum by a simple spot hybridization technique: comparison with results for other viral markers. Hepatology 1983; 3: 379-284.

7 Sheuer PJ. Liver biopsy interpretation. London: Ballière Tindall, 1980: 102-15.

8 Giusti G, Ruggiero G, Galanti GB, Piccinino F, Sagnelli E, Gallo C. Chronic active hepatitis in Italy: a multicenter study on clinical and laboratory data of 1154 cases. Hepato-Gastroenterol 1983; 30: 126-30.

9 Hodges JR, Millward-Sadler GH, Wright R. Chronic active hepatitis: the spectrum of the disease. Lancet 1982; 1: 550-2.

10 Odièvre M, Maggiore G, Homberg JC. Seroimmunological classification of chronic hepatitis in 57 children. Hepatology 1983; 3: 407-9.

11 Papaevangelou G, Kiriakidou A, Vissoulis C, Trichopoulos D. Seroepidemiological study of HBV infections in Greece. J Hyg Camb 1976; 76: 407-9.

12 Callea F, Facchetti F, Favret M, et al. Clinical (with special reference to liver disease), epidemiological, 
genetical, social and psychological implications of intermediate alpha ${ }_{1}$ antitrypsin deficiency ( $\mathrm{Pi} \mathrm{MZ}$ phenotype). J Hepatol 1986; suppl 1: 26.

13 Brechot C, Pourcel C, Hadchouel M, et al. State of hepatitis B virus DNA in liver diseases. Hepatology 1982; 2: suppl 2: 27-34.

14 Omata M, Afroudakis A, Choong-Tsek Liew, et al. Comparison of serum hepatitis $B$ surface antigen and serum anti-core with tissue $\mathrm{HBsAg}$ and hepatitis B core antigen. Gastroenterology 1978; 75: 1003-9.

15 Fattovich G, Rugge M, Brollo L, et al. Clinical, virologic and histologic outcome following seroconversion from $\mathrm{HBeAg}$ to anti-HBe in chronic hepatitis type B. Hepatology 1986; 6: 167-72.

16 Bortolotti F, Cadrobbi P, Rugge M, et al. Evolution of chronic hepatitis B of children towards a 'healthy' HBsAg carrier state: results of a prospective study. J Hepatol 1986; 3: suppl 1: 35.
17 Bortolotti F, Calzia R, Cadrobbi P, et al. Liver cirrhosis associated with chronic hepatitis $B$ virus infection in childhood. J Pediatr 1986; 108: 224-7.

18 Bortolotti F, Cadrobbi, P, Crivellaro C, et al. Changes in the hepatitis $\mathrm{Be}$ antigen/antibody system in children with chronic hepatitis b virus infection. J Pediatr 1983; 103: 718-22.

19 Rizzetto M, Canese MG, Gerin JL, et al. Transmission of the hepatitis B virus associated delta antigen to chimpanzees. J Infect Dis 1980; 141: 590-602.

20 Vegnente A, Larcher VF, Mowat AP, Portmann B, Williams R. Duration of chronic active hepatitis and development of cirrhosis. Arch Dis Childh 1984; 59: 330-5.

21 Bortolotti F, Realdi G, Cadrobbi P, Crivellaro C, Pornaro E. Clinical features and evolution of non-A, non- $B$ hepatitis in relation to the epidemiological background. Ital J Gastroenterol 1982; 14: 86-9. 